\section{UK to brood on CERN pullout}

THE United Kingdom continues to pull up the drawbridge to Europe. The British research councils are to spend the next year making up their minds whether to pull out of the European Organization for Nuclear Research at Geneva (CERN). The decision was announced last week, on the heels of the demonstration by Mrs Margaret Thatcher, the British Prime Minister, at Brussels of her independence from Europe, by Sir David Phillips, chairman of the Advisory Board for the Research Councils (ABRC).

ABRC says that the need to review membership of CERN has been made necessary by the "grave" shortage of funds for the support of civil research in Britain. Two requests for extra funds in the British research budget have been turned down by the government.

The politically sensitive nature of the planned study seems in everybody's mind. The research councils last week

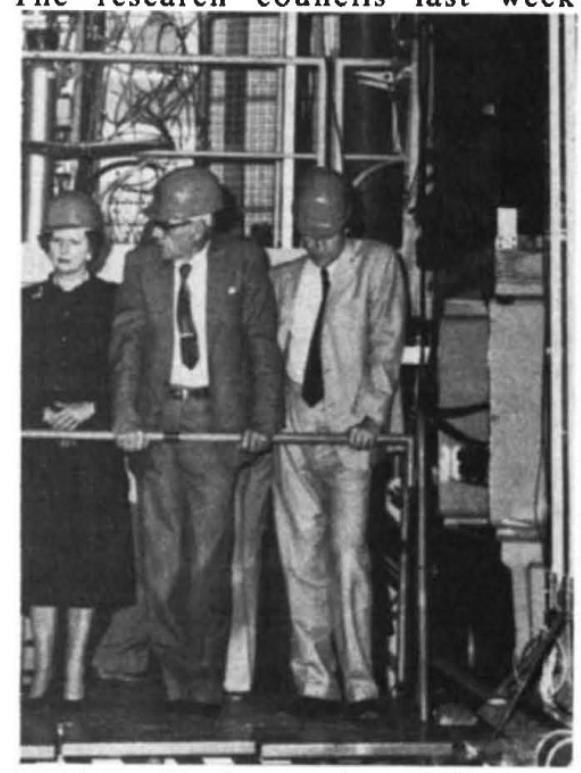

Mrs Margaret Thatcher gets to know CERN.

emphasized that the British commitment to CERN is a treaty obligation which can be ended only by the government. In a letter to the ABRC chairman, also released last week, Sir Keith Joseph, the Secretary of State for Education and Science, insists on the "constitutional distinction" between the "board's advice on a matter and what the government may decide on that advice".

The ABRC plan is that a committee under Sir John Kendrew, president of St John's College, Oxford, president of the International Council for Scientific Unions, chairman of the British National Scientific Committee on Unesco and, until 1982, director-general of the European Molecular Biology Laboratory, will report both to the Science and Engineering Research Council (SERC), which launders the British contribution to CERN, and to ABRC.
The other members of the committee are Sir Jack Lewis (physical chemistry, Cambridge), Professor Kenneth Pounds (X-ray astronomy, Leicester), Sir Francis Tombs (previously with the UK Atomic Energy Authority, now a director of manufacturing and banking companies) and Sir Douglas Hague (chairman of the Economic and Social Research Council). Dr Christopher Llewellyn Smith, the highenergy physics theoretician from Oxford with close links to CERN, is to be an adviser to the review group.

The group, to which other members may be appointed, is expected to report a year from now. On that timetable, given the need for a full calendar year's notice, British membership could not end sooner than 31 December 1986.

The research councils seem to have won from the government the concession that if it is eventually decided to withdraw from CERN, the money saved will be "redeployed" within the science budget. Or, in Sir Keith Joseph's words, "While the level of the science budget for any future year will, of course, need to be considered in the light of all the circumstances at the time, I can say definitely that any such proposal to which the government agreed would not be

\section{Another blow to UK}

BRTISH nuclear and high-energy physics are under pressure other than that of the threat of withdrawal from CERN. At last week's meeting of the Science and Engineering Research Council, when preliminary plans were drawn up for spending during 1985-86, nuclear and high-energy physics were at the bottom of the list.

The council appears to be engaged on its "forward look" for submission to the Department of Education and Science before the budget cycle for the next financial year gets under way. The trick on which the council has embarked, with the objective of introducing flexibility into its budget, is to induce its component spending boards to release a portion of their funds into a general reserve on which all may then make bids. On the showing so far, the science board (small science) seems to be doing best, then engineering and then space science. Increases in these fields will then be paid for by a decrease in the budget of the nuclear science board.

Broadly the argument seems to have gone this way: small science has been relatively under-supported and so should receive more from the general reserve. Engineering, still favoured by the government, has risen threefold in the past decade so that the council leant towards consolidation. But space science has been badly hit both by the policy emphasizing optical astronomy and the general shortage of an occasion for cutting the science budget as a whole".

On the question of what would happen if the British Government decided for political reasons not to follow an ABRC recommendation to withdraw, Sir David Phillips said that he would expect the government to "stand by its commitment".

But Professor John Kingman, chairman of SERC, denied that the proposed study of withdrawal from CERN is a stratagem to saddle the government with separate financial responsibility, saying that no part of his research council's programme is "sacrosanct", that another committee is at work on commitments in space research and astronomy and that the research council contribution to CERN is the largest identifiable item in SERC expenditure some 24 per cent of the total.

There was some confusion last week about the possible abruptness of British withdrawal from CERN. In one breath, Kingman said that "you cannot be an 80 per cent member" and offered the possibility that "our partners would agree to a different pace of development". The review group's terms of reference ask it to consider "the role and extent of international collaboration", suggesting the possibility of renogotiation of the treaty, not outright withdrawal.

By 1987, the first possible year in which the United Kingdom might not belong to

\section{physicists}

funds and so should also be protected.

The upshot is that there was nothing in the kitty for the nuclear science board, which will be left with an even smaller margin than the present $£ 15$ million between its total expenditure and the treaty-determined subscription to CERN. Some high-energy physicists say that the margin is already so eroded that the CERN subscription is ill-used by the British highenergy physics community. These proposals, to be finalized in April, will become part of ABRC's proposals to the British Government, due in the spring. A more radical proposal for internal reorganization is a plan to merge the two most expensive boards maintained by SERC the astronomy, space and radio board and the nuclear physics board. This proposal, first canvassed by SERC chairman Professor John Kingman last summer, is intended to allow peer assessment of the relative merits of high-energy physics and astronomy projects. At present, decisions such as these fall to the council, which does not always have the scientific competence to make judgements.

The effect of such a decision would be to create a single high-spending board accounting for some $\mathbf{4 0}$ per cent of SERC expenditure. An obvious snag is that the big spenders and the small spenders would be set at each others' throats. But council meetings might be shorter. Robert Walgate 